\title{
Contrasting Two Clients in Emotion-Focused Therapy for Depression 1: The Case of "Tom," "Trapped in the Tunnel"
}

\author{
JEANNE C. WATSON ${ }^{\text {a, }}$, RHONDA N. GOLDMAN ${ }^{b}$, \& LESLIE S. GREENBERG $^{c}$ \\ ${ }^{\text {a }}$ University of Toronto \\ b Argosy University \\ ${ }^{\mathrm{C}}$ York University \\ ${ }^{d}$ Correspondence concerning this article should be addressed to Jeanne C. Watson, Professor and Chair, Department \\ of Adult Education and Counselling Psychology, OISE/University of Toronto, 252 Bloor Street West, Toronto, \\ Ontario, M5S 1V6 \\ Email: jeanne.watson@utoronto.ca
}

\begin{abstract}
The objective in this paper is to present a case drawn from a series of randomized clinical trials (RCT) comparing brief (16-20 sessions), emotion-focused therapy (EFT) the process experiential approach with client-centered therapy and cognitive-behavioral therapy in the treatment of depression. A case comparison method that triangulates data from clients' histories, in-session process, post-session questionnaires, and post-therapy outcome measures was used to increase understanding of those factors that contribute to successful and unsuccessful outcomes. The case comparison method examines the role of the working alliance, clients' emotional processing, clients' and therapists' interpersonal processes, and clients' cognitive processing, as well as the specific changes that clients report immediately following their sessions that have been found to be related to therapeutic outcomes. The method is illustrated with two examples one a poor outcome case and the other a good outcome case The poor outcome case of "Tom" is presented in this article, and the good outcome case of "Eloise" is presented in the next article by Goldman, Watson, and Greenberg (2011). These two cases extend and build on the cases presented by the authors in their book Case Studies in Emotion-Focused Treatment of Depression: A Comparison of Good and Poor Outcome (Watson, Goldman, \& Greenberg, 2007), in which six clients, three good outcome and three poor outcome, were compared and contrasted using the case-comparison method.
\end{abstract}

Key words: case studies; randomized clinical trials (RCTs); emotion-focused therapy (EFT); experiential; working alliance; depression; process; outcome; CBT; depression; alliance; case studies; clinical case studies; comparative case studies

\section{CASE CONTEXT AND METHOD}

\section{Overview}

The objective in this paper and the study that follows (Goldman, Watson, \& Greenberg, 2011) is to analyze one poor outcome case and one good outcome case, respectively, to 
Contrasting Two Clients in Emotion-Focused Therapy for Depression 1:

The Case of "Tom," "Trapped in the Tunnel"

J.C. Watson, R. Goldman, \& L. Greenberg

Pragmatic Case Studies in Psychotherapy, http://pcsp.libraries.rutgers.edu

Volume 7, Module 2, Article 3, pp. 268-304, 06-05-11 [copyright by authors]

illuminate the process and structure of process experiential psychotherapy, an emotionally focused treatment (EFT) for depression. The two cases are drawn from two different randomized clinical trials in the treatment of depression that compared EFT with client-centered therapy and cognitive-behavioral therapy.

Information drawn from a number of different perspectives was triangulated to illuminate the underlying processes specific to each, and included process measures, self-report postsession measures, and self-report outcome measures. By triangulating information from clients, therapists, and third party observers, we have attempted to present an in-depth picture of what occurs both in a single session and over the course of a sixteen to twenty week treatment of depression using emotion-focused therapy. The case studies supplement the Greenberg and Watson (2005) text that outlines the treatment of depression using an emotionally focused approach. The present study also aims to augment our understanding of how the therapy works and who responds to brief treatment with EFT in order to better understand the needs of clients and tailor our treatments for their benefit.

Descriptions of the specific measures used in Tom's case study are presented below.

\section{Process Measures}

Process measures were applied by third party observers to rate different types of client processes over the course of treatment. These ratings were assigned using either transcripts of therapy sessions or videotaped recordings. The four process measures used in this case study were designed to identify the ways in which clients processed their emotional experience, their level of cognitive processing, their interaction with their therapists, and their treatment of themselves based on their descriptions of their behavior and actual in-session behavior. As such, they add weight to therapists' observations and clients' self-report measures of outcome. They also help delineate the types of changes that clients made during the course of therapy and provide objective client markers that can be used to guide therapeutic interventions.

\section{The Experiencing Scale (EXP; Klein, Mathieu-Coughlan \& Kiesler, 1986)}

This measure describes the quality of clients' emotional processing during the therapy hour. The scale consists of seven stages that identify the extent to which clients are processing their emotional experience. Stage ratings range from low, indicating that clients are not processing their emotional experience, to high, indicating that clients are reflecting on their emotional experience and making shifts in terms of their views about self and others. The scale evaluates the extent to which clients explore and integrate their inner experience to achieve selfunderstanding and problem resolution (Pos, Greenberg, Goldman, \& Korman, 2003; Watson \& Bedard, 2006; Watson \& Greenberg, 1996).

Clients at Stage 1 discuss events, ideas, and interactions of little or no personal significance and do not refer to their own feelings. At Stage 2, clients refer to others and make reference to the self but do not express emotions. At Stage 3, they begin to pepper their narratives with some references to their feelings, reactions to others, and life events. By Stage 4, clients have shifted from an external frame of reference to an internal one; they reveal their 
Contrasting Two Clients in Emotion-Focused Therapy for Depression 1:

The Case of "Tom," "Trapped in the Tunnel"

J.C. Watson, R. Goldman, \& L. Greenberg

Pragmatic Case Studies in Psychotherapy, http://pcsp.libraries.rutgers.edu

Volume 7, Module 2, Article 3, pp. 268-304, 06-05-11 [copyright by authors]

subjective worldview with their feelings, perceptions, and experiences clearly expressed. Clients at Stage 5 have begun to examine and explore their subjective experience in a purposeful way, reflecting on their emotional reactions and behavior to try to understand them better. At Stage 6 clients have developed new perspectives and feelings about themselves and their world. This stage is characterized by a shift that indicates that clients are able to reframe their problem or to see themselves or others in new ways. Clients at Stage 7 continually refer to their inner world and subjective experience to process events. This stage reveals an ongoing processing of experience that provides new perspectives for solving significant problems (Klein et al., 1986).

The experiencing scale is useful as a guide to gauge clients' awareness of their emotional experience and the productivity of the work involved in experiential therapy. It also indicates when clients have resolved a problem or shifted their understanding so that they are looking at their experiences in new ways. Although shifts can be indicators of dramatic change, they may also reveal clients' evolving conceptualization of a problem. For instance, EXP can reveal when clients change from viewing themselves as victims of their moods to realizing that their selfcritical behavior may be contributing to their feelings of depression. This understanding in turn enables them to commit to changing this way of treating themselves.

\section{Levels of Client Perceptual Processing (LCPP; Toukmanian, 1986)}

The LCPP is used to categorize different types of client cognitive processing in psychotherapy. It takes into account the diversity of information that clients attend to and the kind of mental operations they employ to process information. The LCPP is useful to understand whether clients are analyzing their experience, differentiating their internal feelings and subjective awareness, using rules and external standards to judge their behavior, or acquiring new perspectives that shift their understanding of themselves and others and integrating this information in new ways.

The measure consists of seven discrete categories including undifferentiated statements, elaboration, externally focused differentiation, analytic differentiation, internally focused differentiation, reevaluation, and integration. Level 1 refers to undifferentiated statements that convey a packaged, condensed view of events. They have a glib, pat quality that lacks a sense of reflection or analysis. Level 2 denotes elaborations,those utterances that are descriptive and add information, but are tight unreflective descriptions of events. Level 3 identifies differentiation with an external focus and refers to those observations that are made using an external frame of reference. At this level the client uses external rules and standards to make sense of his or her experience. Level 4 identifies analytic differentiation or those statements that are objective and intellectual. This pertains to statements that show that the client is able to make distinctions among events but does so using systematic logic instead rather than an internal perspective. Level 5 refers to differentiation with an internal focus and describes statements that are made form an internal perspective. They are uniquely personal and convey the speaker's idiosyncratic view of events. Level 6 comprises reevaluation and refers to those statements that reflect the speaker's consideration of alternative ways of viewing experience. These are propositional in nature and suggest a tentative shift in perspective. Level 7 identifies integration and refers to 
Contrasting Two Clients in Emotion-Focused Therapy for Depression 1:

The Case of "Tom," "Trapped in the Tunnel"

J.C. Watson, R. Goldman, \& L. Greenberg

Pragmatic Case Studies in Psychotherapy, http://pcsp.libraries.rutgers.edu

Volume 7, Module 2, Article 3, pp. 268-304, 06-05-11 [copyright by authors]

those comments that show that the speaker has integrated information from a variety of sources to capture a common meaning, infer a relationship, or form a new perspective.

Structural Analysis of Social Behavior (SASB; Benjamin, 1974, 1986)

The SASB measures factors related to interpersonal process. It is based on an "interpersonal circle" (also called an "interpersonal circumplex") model of social behavior defined by two orthogonal axes related to the interpersonal dimensions of affiliation and control. As shown in Figure 1, the interpersonal circles refer to three different contextual foci, called "surfaces. Surface 1 depicts interpersonal process in which the focus is on the other; Surface 2 depicts interpersonal behavior in which the focus is on the self; and Surface 3 depicts intrapsychic behaviors or how the person treats him or herself. Each surface contains 36 interpersonal behaviors that represent unique combinations of affiliation and control. The 36 behaviors on each surface may be collapsed into eight psychometrically validated clusters (Benjamin, Foster, Roberto \& Estroff, 1986), which are shown for each surface in Figure 1.

SASB is a useful measure to help examine how clients and therapists are interacting with and treating each other in the session. As such it provides a good window into the therapeutic alliance and how it unfolds over the course of therapy. In addition, SASB ratings highlight how clients treat themselves (Watson, 2010). It illuminates moments when clients are being selfcritical, oppressive, neglectful, self-accepting, or nurturing. By tracking these behaviors over the course of therapy, clients' problematic ways of interacting with themselves and others can be identified and any changes that occur can be monitored over the course of treatment.

In the narrative below, interpersonal behaviors that occur in sessions are referred to by two numbers: the first number refers to one of the three surfaces, and the second number to one of the eight clusters within a particular surface.

\section{Self-Report Post-Session Measures}

The changes that clients identified after every session on two different self-report measures were examined as an indication of the clients' overall experience of therapy and the changes they were making. The specific measures included are described below.

\section{Client Task Specific Change Measure-Revised}

(CTSC; Watson, Greenberg, Rice \& Gordon, 1996)

The CTSC is a post session measure that consists of sixteen questions that ask clients to identify specific changes they experienced in the session on a 7-point scale (Watson, Greenberg, Rice \& Gordon, 1998). For example, clients are asked whether they resolved lingering bad feelings toward a significant other; whether they came to a better understanding of how their thoughts affected their feelings and behavior as a result of the activities they performed during the session. A total mean score comprising all the items provides an index of client change during the session. The items are relevant to both emotion-focused therapy and cognitive-behavioral therapy. Clients with scores of five or higher are reporting moderate to high amounts of change 
Contrasting Two Clients in Emotion-Focused Therapy for Depression 1:

The Case of "Tom," "Trapped in the Tunnel"

J.C. Watson, R. Goldman, \& L. Greenberg

Pragmatic Case Studies in Psychotherapy, http://pcsp.libraries.rutgers.edu

Volume 7, Module 2, Article 3, pp. 268-304, 06-05-11 [copyright by authors]

in terms of their understanding of their problems, the way they are treating themselves, and their feelings about themselves and others (Watson, Shein \& McMullen, 2009).

Working Alliance Inventory (WAI; Horvath \& Greenberg, 1989)

This is a 36 item self-report questionnaire to assess the working alliance on the dimensions of tasks, goals, and bonds. Using a 7-point scale, clients rate the extent to which they agree with the therapist on the tasks and goals of therapy and whether they feel their therapist likes them. The measure has good inter-item reliability (Horvath \& Greenberg, 1986). Clients with scores of five or higher are considered to have good to excellent working alliances with their therapists.

\section{Self-Report Outcome Measures}

In addition to the post-session measures, clients completed measures at the beginning, mid-point, and end of therapy that served as outcome measures (Watson, Goldman, \& Greenberg, 2007).

Beck Depression Inventory (BDI; Beck, Ward, Mendelson, Mock, \& Erbaugh, 1961)

This is a 21-item questionnaire that measures various aspects of depression, including affect, cognition, motivation, behavior, and somatic symptomology. This instrument has been found to be a reliable and valid measure of depression that is sensitive to clinical changes in the depth of depression. Scores of 1-10 indicate no depression; scores of 10-15 indicate mild depression; and scores of 15 or higher indicate severe depression. Test-retest reliability ranges from 0.6 to 0.9 (Beck et al., 1961). Beck, Steer, and Garbin (1988) report validity coefficients ranging from .66 to .86 and internal consistency coefficients ranging from .73 to .93. Internal reliability tests have yielded results ranging from .82 to .93 (Beck et al., 1961).

Inventory of Interpersonal Problems (IIP; Horowitz, Rosenberg, Baer, Ureno, \& Villasenor, 1988)

The IIP is a self-report instrument consisting of 127 items. Responses are scored using a 5-point Likert scale with responses ranging from 0 to 4 . It is used to measure the severity of distress arising from interpersonal sources. Respondents rate the degree to which each situation is experienced as being problematic. The authors report overall test-retest reliability between 89 and .98, and internal consistency ranging from .89 to .94 (Horowitz et al., 1988). With respect to validity, the IIP has been shown to be sensitive to clinical change and has correlated well with alternative measures of clinical improvement, including the SCL-90 (Horowitz et al., 1988).

\section{Procedures for the Randomized Clinical Trials}

Clients were recruited through advertisements over the radio, in newspapers, and posters in a large metropolitan city. During the first assessment interview, they were assessed using the Structured Clinical Interview for DSM-IV (SCID IV; Spitzer, Williams, Gibbon, \& First, 1995) and a clinical history was obtained to determine whether clients met the criteria for a diagnosis of 
Contrasting Two Clients in Emotion-Focused Therapy for Depression 1:

The Case of "Tom," "Trapped in the Tunnel"

J.C. Watson, R. Goldman, \& L. Greenberg

Pragmatic Case Studies in Psychotherapy, http://pcsp.libraries.rutgers.edu

Volume 7, Module 2, Article 3, pp. 268-304, 06-05-11 [copyright by authors]

Major Depressive Disorder. The clients who met this criterion were randomly assigned to either EFT or a comparison treatment group and received 16 - 20 sessions of individual psychotherapy for 60 minutes once a week. Clients were seen at outpatient clinics affiliated with large metropolitan universities. In the interests of confidentiality, clients' identities have been changed.

\section{THE CLIENT}

Tom was in his mid-forties and single when he sought psychotherapy for his depression. He came to therapy because he felt old and washed up. He had failed to achieve recognition for his work and was feeling drained and disappointed in himself. He described himself as an underachiever who had shown great promise in his youth but had failed to live up to his potential. His family was disappointed in him and accused him of wasting his life. Tom was critical of himself, citing his lack of a career, family, house, and car as indicators that he was not successful like most middle class people he knew. He worked the night shift as a security guard and had accumulated few material possessions and friendships. When he came to therapy, he was unhappy with his work and felt that he was getting too old to do some of the chores required by his job, since he had injured his back. Tom was a loner who had lost touch with friends over the years. He had become quite reclusive since he stopped teaching at a community college and broke off a relationship with a woman he loved in his mid-thirties.

\section{THE GUIDING CONCEPTION: EFT FOR DEPRESSION}

In addressing Tom's depression, the model of “process experiential therapy, an emotionfocused treatment” (EFT) was used (Greenberg, Rice \& Elliott, 1993; Elliott, Watson, Goldman \& Greenberg, 2005; Greenberg \& Watson, 2005). In EFT, depression is seen to result from problems in affect regulation as a result of maladaptive, blocked, and unprocessed emotional experience (Greenberg, Elliot, \& Foerster, 1990; Greenberg \& Watson, 2005; Watson, Goldman \& Greenberg, 2007). A goal of EFT therapists is to help clients access and process their emotional experiences and construct new meanings and ways of being in the world. A primary objective in EFT is to change the emotion schemes underlying clients' depressions by deepening their experiencing and emotional processing. There is some evidence that helping clients access and process their emotional experience in the session is related to good outcome (Greenberg \& Watson, 1998; Watson, Gordon, Stermac, Steckley \& Kalogerakos, 2003). Furthermore, emotional arousal and deeper experiencing are significantly related to outcome in the resolution of client depression and unfinished business (Pos, Greenberg \& Goldman, 2003; Greenberg \& Foerster, 1996; Greenberg \& Malcolm, 2003; Paivio \& Greenberg, 1998; Watson \& Bedard, 2006).

The two basic goals that guide the practice of EFT are to establish an empathic healing relationship and to promote the resolution of specific tasks. Resolving tasks requires clients and therapists to access and deepen the clients' emotional processing in order to facilitate changes in how they treat themselves and others (Elliott, Watson, Goldman \& Greenberg, 2003; Greenberg, Rice \& Elliott, 1993; Greenberg \& Watson, 2005; Watson, Goldman, \& Greenberg, 2007; Watson, 2010). 
The Case of "Tom," "Trapped in the Tunnel"

J.C. Watson, R. Goldman, \& L. Greenberg

Pragmatic Case Studies in Psychotherapy, http://pcsp.libraries.rutgers.edu

Volume 7, Module 2, Article 3, pp. 268-304, 06-05-11 [copyright by authors]

\section{Developing a Healing Relationship}

There are three objectives in establishing and maintaining a healing relationship in EFT: first, therapists attune themselves to their clients' moment-by-moment emotional experience; second, therapists communicate empathic understanding, acceptance, and genuineness to their clients; and third, therapists facilitate collaboration with their clients on the tasks and goals of therapy. Experiential therapists attend to clients' style of speech, vocal quality, body language, and emotional processing style to guide their moment-to-moment interventions. They are particularly attuned to clients' emotional experience and work to track it over the course of the session in order to respond empathically. This requires that experiential therapists be present and highly focused on their clients' experience, as they must attend to the nuances of clients' narratives and integrate this with information from previously obtained histories and other nonverbal sources. EFT therapists try to stay responsive to new and emergent experience in their clients and attend to shifts in clients' perspectives and understandings.

As they track and try to amplify their clients’ emotional experience, experiential therapists work to create a safe environment in which their clients feel genuinely accepted and understood. Communicating empathy, acceptance, and genuineness provides an environment in which clients can feel free to explore their experience and confront their wounds, fears, anxieties, and pain, as well as the parts of their experience that they view as shameful. In order to have therapeutic impact, it is not enough that therapists feel or think they understand their clients' experience; the therapist's understanding has to be communicated and received by the client. EFT therapists try to provide a safe environment for their clients to promote therapist-client bonding, hope, and encouragement at times when clients may feel quite demoralized (Watson, Goldman, \& Greenberg, 2007).

In order to forge a positive therapeutic relationship, EFT therapists need to establish agreement and collaboration on the tasks and goals of therapy. Initially, EFT therapists listen to clients' narratives to identify problematic aspects of their experiences. It is important to come to a shared understanding of what clients are doing and experiencing that may be contributing to their depressions. Often this requires a subtle reframing of clients' experiences by the therapists in order to ensure a fit with the therapists' conceptualizations and ways of working. For example, it is important that clients agree that talking about their feelings and subjective experience can be productive. Clients need to feel that the way in which their therapists think about the clients' problems and the suggestions they make to facilitate clients' resolution of their problems make sense and fit with clients' expected goals and outcomes. While establishing a productive therapeutic relationship is often the primary concern early in therapy, it continues to be vital throughout treatment, as clients and therapists engage in the exploration and resolution of problematic issues.

\section{Task Components}

An important objective of EFT therapists is to facilitate resolution of specific tasks and to promote differential processes in clients during the sessions. Differential processing refers to the practice of facilitating different client processes at different times-for example, attending to 
Contrasting Two Clients in Emotion-Focused Therapy for Depression 1:

The Case of "Tom," "Trapped in the Tunnel"

J.C. Watson, R. Goldman, \& L. Greenberg

Pragmatic Case Studies in Psychotherapy, http://pcsp.libraries.rutgers.edu

Volume 7, Module 2, Article 3, pp. 268-304, 06-05-11 [copyright by authors]

various emotional states, actively expressing emotional experience, or reflecting on the meaning of a reaction or behavior; and helping clients resolve specific tasks like unfinished business, conflict splits, or problematic reactions (Elliott et al, 2003; Greenberg \& Watson, 2005; Watson, Goldman, \& Greenberg, 2007).

A second objective is to foster clients' growth and choice. This is done by fostering selfdetermination and in-session decisions as clients focus on and become aware of their perceptions, feelings, and needs. As they become aware of their needs they are encouraged to reflect on them and find ways of realizing them in their current life situations. EFT therapists also focus on their clients' strengths to help them change.

A third objective is to facilitate resolution of the cognitive-affective difficulties that clients have brought into treatment. This requires that therapists balance moment-to-moment responsiveness with active stimulation. To maintain this balance EFT therapists continually monitor their clients' reactions to determine whether they require empathic validation and exploration around a particular issue or a more active collaborative stance to resolve unfinished business or to find new ways of treating themselves, for example becoming less self-critical. (Greenberg et al, 1993; Greenberg \& Watson, 2005; Watson, Goldman, \& Greenberg, 2007).

\section{The Phases of Treatment}

Greenberg and Watson (2005) have identified three different phases over the course of treatment. These include the bonding and awareness phase, the evoking and exploring phase, and the transformation phase. Although these phases are presented sequentially they recur over the course of therapy and feed into each in a recursive pattern.

\section{The Bonding and Awareness Phase}

This is the first stage of treatment during which clients and therapists establish a therapeutic relationship and begin to develop a focus for the treatment. During the bonding and awareness phase therapists work to make clients more aware of their emotional experience as they begin to share the details of their lives and the reasons for coming into therapy. This initial stage of therapy is very important as clients begin to become more aware of the impact of events on them and their own unique way of responding. As therapists begin to develop a sense of clients' responses to events and develop an awareness of the major life events in their clients' lives and how their clients have coped, they can often begin to see why clients respond as they do to specific events. This allows EFT therapists to tailor their treatments so that their interventions are relevant and meaningful for each client. For example, a therapist might observe that a client is quite harsh with himself expecting himself to assume total responsibility for his own and others' well being. Listening to the client's life story, the therapist may learn that the client's parents were alcoholics and emotionally unavailable so he learned that he needed to look out for himself and his siblings and that his sense of responsibility has carried over into other areas of his adult life. At the same time the therapist may also be aware that the client learned to invalidate his feelings as a child and continues to do so as an adult so that he is not aware of his moment to moment experiencing, forcing himself to act regardless his feelings and needs. 


\section{The Evoking and Exploring Phase}

During this phase, EFT therapists try to promote clients' emotional experiencing in the session. Therapists help clients explore their experience in order to evoke their emotional reactions to events so that these can be processed in conscious awareness. Clients are encouraged to experience their emotions and become aware of their bodily felt sense of events that they may have disowned, or denied, previously. As clients explore and become aware of their emotional experience during the session they are able to articulate and identify the emotion schemes that underlie their reactions and ways of being in the world. These can then be examined and reflected upon to potentiate changes in clients' behavior. In order to evoke clients' emotional experience, EFT therapists listen for moment to moment markers to help them identify live moments in clients emotional experiencing that may need to be processed. To do this therapists listen to clients' vocal quality, the words and phrases they use to describe their experience, their emotional processing, and non-verbal behavior. In addition they attend to specific task markers to help identify particular cognitive-affective tasks that may be problematic for clients. EFT therapists listen for clients' expressions of problematic reactions, expressions of intense emotion, self-critical comments or exchanges with significant others that leave clients with negative feelings. It is important to help clients become aware of their emotional experience so that they can symbolize it in words and come to understand it in new ways. Once clients are aware of and understand their emotional experience they are in a better position to know what they need and to develop new ways of behaving to satisfy their needs and goals.

\section{The Transformation Phase}

This final phase is concerned with transformation or constructing alternative ways of responding. During this phase EFT therapists help clients develop new ways of viewing their experience and focus on helping clients construct new ways of treating themselves and of being with others. Once their emotional experience has been processed so that clients see its import and the significance of events in their lives and have identified the triggers for their reactions and their characteristic ways of responding, they are able to develop alternative responses and new ways of being that are more satisfying. During the transformation phase clients are able to reflect on their experience and come to see it in new ways and regulate their affective experience more effectively. These were the principles that informed the practice of EFT for depression with Tom.

\section{"Chair" Work}

In EFT, two important procedures that are employed in the therapy room to accomplish clients' goals are the "two-chair” technique and the "empty chair” technique. Goldman \& Watson (2011) describe these as follows:

In two-chair work, one part of the self is instructed to express the harsh criticism or negative self-statements in order to evoke the emotional reactions to the criticisms. These reactions, such as hopelessness, fear, or shame, are transformed by accessing alternate, more primary emotions such as sadness at loss or anger at violation. Once the client has accessed their primary emotions in response to the harsh critic they are able to more clearly see what 
Contrasting Two Clients in Emotion-Focused Therapy for Depression 1:

The Case of "Tom," "Trapped in the Tunnel"

J.C. Watson, R. Goldman, \& L. Greenberg

Pragmatic Case Studies in Psychotherapy, http://pcsp.libraries.rutgers.edu

Volume 7, Module 2, Article 3, pp. 268-304, 06-05-11 [copyright by authors]

they need. Clients are encouraged to symbolize and express primary feelings and associated needs and use these to combat their negative cognitions. This leads to a softening of the harsh criticism and a negotiation and integration of the two previously disparate aspects of self (Greenberg, Rice, \& Elliott, 1993).

Empty chair work for unfinished business involves the expression of previously suppressed primary emotion such as hurt and anger to an imagined significant other sitting in the empty chair. This leads to an expression of unmet needs. Clients take the perspective of the other at this point in the dialogue, which can lead them to access a new view of the other. Resolution has been shown to involve an assertion of the self and an understanding of the other; and a letting go, forgiveness, or affirmation of the other's accountability for his or her actions (Greenberg \& Malcolm, 2002).

\section{ASSESSMENT}

Tom was very intellectual and analytical. He was articulate and well read but was shut off from his emotional life. He was unaware of his emotions and found it very difficult to talk about and describe what he was feeling. He had great difficulty accessing and labeling his feelings in the session and was most relaxed when talking about an invention he had been working on for a number of years. On the few occasions when feelings did well up he would freeze, become speechless and sweat profusely. When his therapist explored what was happening for him he said he felt awkward and exposed. Tom's physical presence was in sharp contrast to his reported mood and lifestyle. He was a tall well-built man with a powerful presence. He could be quite charismatic when describing his work and noted that he had been a good lecturer when he taught classes at a community college.

Tom came from a large family with eight children. When he came to therapy he reported little contact with his parents and kept in touch with only one of his siblings. He described his family as disengaged. To illustrate the lack of cohesion at home he recalled that when he was a young adult his younger sister thought that he was a visitor when he returned home from University for the summer holidays. He described his home as being "like a bus station—always busy with lots of people coming and going." As a child in the midst of all the activity he recalled feeling lost and forgotten. As Tom described his childhood it became clear that he felt neglected. He acknowledged that as children he and his siblings were well dressed, had enough to eat, and a roof over their heads but other than that he recalls his parents as aloof and inaccessible. He had been an excellent student and was athletic, so he had been popular at school with an extensive network of friends.

Tom first faltered when he went to a university to study engineering. Although he did well, he dropped out of the program in his third year as he did not feel that it would lead to a satisfying career and completed a general arts degree instead. Subsequently he traveled with some friends for a year. During this time he became involved with some political causes and began to work with troubled youth. He found this experience very difficult as the people he was working with reminded him of his own pain and neglect. He felt inadequate to help them with their problems so he quit and returned to the city, where he found employment as a parking attendant, working the night shift. He enjoyed this position as it gave him a lot of flexibility. He 
discovered that he had a lot of time during the evenings when he was alone on the job so he began to read widely and taught himself engineering after forming connections with people in the engineering department at the university. During this time he began working on some projects and inventions of his own. He became involved in a project that was his life's work. He was passionate about pursuing his interests even though he was not employed and did not have formal training in the subject matter. Later on he taught at a community college.

A few months prior to entering therapy his invention was rejected by an engineering firm and harshly critiqued by an expert in the field. This was crushing to Tom who felt that his efforts of the past 10 years had been wasted. The rejection seemed to suck the life out of him. By the time he came to therapy he was exhausted and despairing about what he had achieved in life. He felt hopeless that he could recover the time he had lost nor did he believe that he could do something more fulfilling and productive with his life.

\section{FORMULATION AND TREATMENT PLAN}

It was clear early on in therapy that Tom, as a result of his childhood experience, was neglectful and critical of himself. He was cut off from his emotional experience and unable to process it so that he was without a personal reference point to direct him. In spite of his intelligence and the promise he had shown as a young boy, he did not find work that was fulfilling and that would insure his material well being. Instead, as a young man he had adopted a non-conformist lifestyle. Now in middle age he was experiencing a deep crisis about the meaning and purpose of his life. He felt exiled from society and hopeless about regaining entry. He was regretful that he had not worked to build a more conventional lifestyle. As he examined his life, Tom was overwhelmed by shame and despair. He coped by remaining very intellectual in his preoccupations so that he did not have to confront his deep loneliness, sadness, and shame.

In addition to his vocational crisis, Tom's lack of close nurturing relationships as a child made him extremely shy and embarrassed about himself and his physical functions and unable to form intimate relationships as an adult. He was also unable to share or talk about his feelings with others, which made it extremely difficult for him to connect with them. By the time he came to therapy he had very few people in his life as he had withdrawn from others becoming ever more reclusive. To cope with his despair, he tried to numb himself to his environment and feelings by watching television and distracting himself with books.

By the time he entered therapy he was feeling quite desperate but was uncertain that it would be useful. Moreover he found it very difficult to be in therapy especially with the requirement that he talk about himself as opposed to ideas. A primary objective early on in treatment was to get him engaged in the process and to help him become aware of his feelings and the way in which he treated himself to help him see how he might be contributing to his feelings of depression. His therapist also spent time exploring different career and job opportunities with him to try to activate his strengths. 


\section{COURSE OF THERAPY}

\section{Sessions 1-3. Bonding and Awareness}

\section{$\underline{\text { Session } 1}$}

During the first five sessions his therapist worked to engage Tom in therapy. In the first session Tom informed his therapist that he would be leaving town in three months and unable to complete sixteen sessions of treatment. At the first session the client seemed defensive and guarded. He expressed his confusion about the process of therapy and had difficulty selfdisclosing, asking "Is it all up to me?" With this question it was apparent to his therapist that the client did not expect to be able to rely on her and that he saw his struggle in solitary terms, assuming that he would be working alone with little support. His therapist reassured him that they would be working together and described how therapy worked. A little later, when asked what he would like to achieve in therapy, he said he was uncertain other than feeling better, but that as the expert surely his therapist could tell him what he needed to do. On further prompting the client then described what had brought him in and how despairing he felt that he had lost faith in his invention. He acknowledged that part of him yearned for recognition and acknowledgement. With great difficulty he admitted he had dreamed of making a contribution but realized that that was extremely unlikely in the future. He expressed how tired and exhausted he felt. At the end of the session he and his therapist agreed to work on alleviating his depression.

\section{$\underline{\text { Session } 2}$}

In the second session the client admitted that he was uncomfortable talking about himself and that it was hard speaking about his emotional life. He acknowledged that he tried to avoid social situations and that it was hard to tune into his feelings. He said that it was difficult being around people as he felt he had nothing to offer and he was intolerant of their shortcomings. The only thing that got him excited was his invention but he had abandoned it. He described himself as "trapped in a tunnel" with no way out. He was quick to reassure his therapist that he did not consider suicide an option because of his spiritual beliefs. As he described his experience, his therapist became aware that he was often ironic about himself and that he would play devil's advocate as he tried to represent both sides of a situation or story. His therapist observed how critical he was of himself and suggested this might be something to work on in therapy to alleviate his depression. The client observed that he was numb and had learned to get along like that and was worried about disturbing the equilibrium.

\section{$\underline{\text { Session } 3}$}

The client's fear of change reasserted itself in the third session. His therapist was still working to formulate a focus for treatment with which the client could agree. Tom said he was reluctant to change, as things were comfortable the way they were and that he had successfully avoided his feelings for 45 years and did not have the tools to begin to process them. He said that he felt handicapped. As he spoke about engaging in therapy his therapist observed that he 
The Case of "Tom," "Trapped in the Tunnel"

J.C. Watson, R. Goldman, \& L. Greenberg

Pragmatic Case Studies in Psychotherapy, http://pcsp.libraries.rutgers.edu

Volume 7, Module 2, Article 3, pp. 268-304, 06-05-11 [copyright by authors]

had broken out in a sweat. The client acknowledged that he felt very anxious saying that his emotional needs were neglected as a child. In order to facilitate his access to his feelings his therapist worked with him using empathic interventions to help him articulate his story. As they did this the client recalled that he often felt sad, lost, and lonely as a child and felt like an imposter with his family. Emotions were not talked about at home. Even though on the outside things looked fine, on the inside he felt disconsolate and lonely. His therapist tried to help him articulate his experience of childhood:

T: You say that you had a sense of being kind of, well, rejected? I mean it sounds like your mom is really busy, with lots of people to take care of, and lots to do...

C: And also...

T: with people in the house...

C: Yeah.

$\mathrm{T}$ : and then you happened to be a quiet kid?

C: Yeah.

T: So you're not demanding, and you have this appearance that living in the world is okay?

C: Yeah.

T: But really, it's not?

C: Yeah.

T: You're actually feeling lonely...

C: And also...

T: out of sync?

Here the therapist is trying to flesh out the clients' narrative and his inner experience of growing up in a large family. The client agrees that he felt emotionally dislocated and alienated living at home as a child. The client's emotional processing is limited (Exp 2; LCPP 1), as he does not add to what his therapist is saying but merely agrees with her. Although he is inhibited in his responding, he goes along with his therapists' understanding and view of the situation (SASB 2-4). At this point in the dialogue Tom shifts perspective and tries to excuse his parents saying that they had a lot of difficulties that they had not resolved with their own families. This can be viewed as his dismissal of and neglect of his own experience (SASB 2-1). After acknowledging this, his therapist tries to keep the focus on Tom and the impact that his childhood experiences had on him.

C: And also, my parents aren't really that good at because...they got their own stuff that they never resolved with their siblings. I mean, you know so...

T: Hmm, hmm. So emotions aren't talked about, is that what you're telling me?

C: That's right. I used to say that living in my house was like living at the bus station because there were lots of people around but they were...they were emotionally strangers, you know?

T: Ships passing by? 
The Case of "Tom," "Trapped in the Tunnel"

J.C. Watson, R. Goldman, \& L. Greenberg

Pragmatic Case Studies in Psychotherapy, http://pcsp.libraries.rutgers.edu

Volume 7, Module 2, Article 3, pp. 268-304, 06-05-11 [copyright by authors]

C: Yeah.

T: And how did you feel as a child, I mean as you describe it as an adult?

C: As an adult?

T: So looking back how do you feel about all these disconnected people kind of sharing this house?

C: Yeah, yeah. And as matter of fact, my youngest brother, who is now my best friend really, or at least amongst my siblings, my really only close friend amongst my siblings, but because he is considerably younger than me, and also I went away to university which none of my other people did and that changed a lot. But I was away at university and then, I would be back in the summer, but you know, when you're in university you don't' hang around and I was always out - my youngest brother told me that he thought I was a boarder (Laughs). You know, when he was like about 7.

Here the client does not address the therapist's question about his feelings but goes on to describe what it was like living at home. He describes his situation at home but does not talk about its emotional impact on him (EXP, Stage 2; LCPP, Level 2). Although he is freely selfdisclosing and expressing himself (SASB surface 2 -cluster 2), he asserts himself by not following the therapist's lead (SASB Surface 2, Cluster 1). After describing this sad anecdote the client laughs. This may be viewed as a way in which the client neglects himself as he tries to avoid facing the impact of his experience by laughing (SASB Surface 1, Cluster 8). His therapist tried to refocus him on his feelings and heighten them to try to get at the impact of living in a large, disconnected family.

T: He didn't think you belonged to the family?

C: (Laughs) that's right?

T: Hang on, you're laughing at that?

C: Well, it's funny, right?

T: How are you feeling? (The therapist asks in a soft tone of voice)

C: Well, no that didn't affect me...

$\mathrm{T}$ : It makes me feel real sad?

C: Oh, well, okay. Well, that's just...

T: How do you feel inside?

C: It's funny but that didn't bother me, that just...

T: But when you talk about your house...

C: Yeah.

T: Being like a bus station, what do you feel inside?

C: I guess I'm just, I mean it's a long time ago, so I just sort of accept it —-that's the way it was. 
The Case of "Tom," "Trapped in the Tunnel"

J.C. Watson, R. Goldman, \& L. Greenberg

Pragmatic Case Studies in Psychotherapy, http://pcsp.libraries.rutgers.edu

Volume 7, Module 2, Article 3, pp. 268-304, 06-05-11 [copyright by authors]

T: But if you think about it, I mean if you I guess focus on it, what do you feel? What else other than accept it? I'm not saying what do you think about it, I'm saying what do you feel about it?

C: Hmm, hmm. I don't know really.

The therapist tried to have the client label his feelings. After he acknowledges that he does not know what he feels, she shares how she sees it changing the experience from sadness to loneliness to see if that view would resonate more with him. It does.

T: It strikes me as pretty lonely, uhm...

C: Well it is and it was.

T: Kind of dispossessed...?

C: Yeah.

T: Kind of not really having a safe place? It kind of makes me feel a little sad.

C: Well, it was-yeah. I mean-yeah, I was sad...

T: You did feel sad?

C: Yeah a lot and lonely, and yet, I'm sure nobody knew.

T: Hmm, hmm. There was nobody to share that with?

C: Right. And I don't know this for a fact but I just suspect there were kids that probably looked at me and figured, "Boy that guy has got it made. He's good at school, you know—base ball..."

$\mathrm{T}$ : So, on the outside it looked...like everything was okay?

C: Yeah.

T: But inside it wasn't true?

C: It was-yeah.

T: Inside was a lonely, sad, little guy?

C: Yeah-that's right.

T: Who sort of longed for something.....what - to connect with other people...to be seen?

C: Yeah, I probably didn't know it then but you know, yeah-yeah, that's right. But you know, I guess maybe because I was smart enough I knew how to get along?

T: So you were able to kind of make your way even...

C: Sort of-yeah that's right. But you know whatever, I mean where am I? That's the problem.

The client has been able to acknowledge and express how difficult it was for him as a child (EXP Stage 4; LCPP, Level 5; SASB Surface 2, Cluster 4; SASB Surface 1, Cluster 1; and SASB Surface 1, Cluster 4). However he quickly becomes self-critical (SASB surface 1- cluster 6). In spite of giving the appearance of getting along as a child and adolescent he expresses disappointment and concern with his current life situation. This prompts the therapist to frame his depression in terms of his self-critical behavior. The client rejects this view saying he is 
being quite objective. It is clear that the client and therapist need to do more work to achieve a shared view of the client's problem. This likely would involve more exploration of his experience and the impact it had on him so as to build a stronger, more compassionate way of treating himself.

His therapist tries to follow the protocol and suggests a two-chair exercise to see whether she can help the client see the detrimental effect such a harsh view of himself has on his mood and well being and establish some agreement on the tasks that will be worked on in the brief amount of time they have together. The client is judging himself by external standards and feels he comes up short (EXP, Stage 2; LCPP, Level 3; SASB Surface 3, Cluster 5; SASB Surface 3, Cluster 8; and SASB Surface 2, Cluster 2).

T: Okay, so that's the critical part of yourself right, that continues to put you down...

C: I guess it's critical but I mean, you know, I can be objective too. I mean...

T: It seems important; you know and could be contributing to your depression. That is one of the things we could work on while you are in here. I mean you keep putting down what you have done...

C: But what have I done, I haven't done anything. I mean that's the thing, that's what's really, that's why the future is so bleak.

The client dismisses everything he has done in his life. Instead of following the client's sense of despair, the therapist suggests they experiment with a task.

T: Do you want to try an exercise?

C: Okay.

T: This may sound hokey, but sometimes it really does help if we can kind of get those criticisms out in the open, okay? It sometimes helps to kind of split them apart so that, they become clearer. Can you tell me? Imagine this is the side that criticizes you. I imagine some of what you say to him is that you failed, that you haven't gotten anywhere; what have you done with your life? maybe even you're useless-I don't know what are the messages? Can you articulate some of those messages, and we will pretend there is another part of you over here and see where that goes.

C: Hmm, hmm.

The therapist notices the expression on the client's face, and instead of going on with the task the therapist responds to the client's experience in the moment and asks him to differentiate and express his feelings. When he replies the therapist shifts focus to what is happening between them and tries to dialogue about the relationship.

T: But in part it's that kind of evaluation that makes you so depressed (the therapist speaks softly) right? What's happening right now — are you sad?

C: Maybe anxious, yeah.

T: You're feeling anxious right now—at the thought of doing this?

C: Yeah. 
The Case of "Tom," "Trapped in the Tunnel"

J.C. Watson, R. Goldman, \& L. Greenberg

Pragmatic Case Studies in Psychotherapy, http://pcsp.libraries.rutgers.edu

Volume 7, Module 2, Article 3, pp. 268-304, 06-05-11 [copyright by authors]

T: What seems hard about it?

C: Well...

T: Am I getting too close?

C: Maybe or I'm not sure, well, actually, I'm not sure what we're doing so I don't know.

T: You're not sure what we're doing?

C: I'm not sure what we're supposed to do.

T: I want you to criticize yourself.

C: And talk to the chair-that's it, don't look at you?

T: Well, it's better just to criticize yourself, I don't mind if you look at me occasionally or directly to the chair, it will emerge, can you trust the process?

C: I don't know. I'm being honest about this—okay.

$\mathrm{T}$ : This feels like we're crazy?

C: No, not crazy, I mean-no not that I, I'm not suggesting, I'm sure you know what you're doing and its probably a good technique, but I'm not—okay what do I do?

T: I just want you to criticize yourself, I just want you to articulate the messages that you give yourself, some of them, you know, you already said, I just sort of want you to express them. How do you criticize yourself, how do you put yourself down? This is what I hear you kind of doing all the time.

Here the therapist is trying to be helpful and protective (SASB, Surface 1, Cluster 4) but also trying to manage the process (SASB, Surface 1, Cluster 5). The client is confused by the task and says that it makes him feel anxious (SASB Surface 2, Cluster 1, and SASB Surface 2, Cluster 2). It would have been useful at this point for the therapist to give the client a rationale for articulating the criticisms and to suggest to him that once the criticisms were out in the open, then they could develop an antidote or alternative view to try to change them. Even though she does not do this the client reluctantly agrees to follow and defers to his therapist (SASB, Surface 2, Cluster 5) by trying to engage in the task as suggested.

C: Yeah.

T: What is it?

C: I wasted my life.

T: Okay. So you've wasted your life-hmm, hmm.

C: I'm 45 years old, I got no future-what am I going to do?

$\mathrm{T}$ : Oh so you're feeling hopeless over here?

C: Yeah.

T: So you're feeling despair over here-it's not just...

C: Yeah. 
The Case of "Tom," "Trapped in the Tunnel"

J.C. Watson, R. Goldman, \& L. Greenberg

Pragmatic Case Studies in Psychotherapy, http://pcsp.libraries.rutgers.edu

Volume 7, Module 2, Article 3, pp. 268-304, 06-05-11 [copyright by authors]

$\mathrm{T}$ : Okay, come over here (Client switches chairs), come over here because this is the feeling side, are there any other messages that you say, "You've wasted your life, you're 45, what are you-you're washed up-is that your message?

C: I don’t know, but mostly I don't see any future. I mean I just feel useless in a way.

T: You're washed up—-there's no future. You kind—-You just really wasted your time.”

C: Yeah that's right.

T: How do you feel over here when that side says, "You wasted, I mean there is no future," how do you feel?

C: I agree (Laughs).

Here we see a shift in the client's responses, which would be rated as Level 5 on LCPP as the client is providing his internal frame of reference and a differentiated unique perspective on his situation. In terms of SASB, the client is going along with his therapist's suggestions (Surface 2, Cluster 5); however he is being harsh, self-indicting, and oppressive as he puts himself down and tells himself he has failed (SASB, surface 3, Cluster 6). The client's agreement with the critic represents an impasse in two-chair work. This may indicate that the therapist needs to heighten the criticisms to identify the one that facilitates the client's awareness of how painful it feels to treat himself like that so that he can tell the critic to stop and request support and compassion instead.

The client's response to heightening can provide useful diagnostic information to direct the therapist's responses. If heightening fails, the therapist probably needs to revert to a more empathic response style to help the client begin to formulate a narrative and develop a stronger sense of self and sense of his pain in order to combat the oppressive critical voice. To heighten the impact of the critic the therapist asks the client to criticize himself some more.

T: But that side sort of feels bad, can you criticize him some more?

C: (Laughs). I don't know.

$\mathrm{T}$ : What are the other things that you say to yourself, what are some of the things your friends say to you or you imagine them saying to you?

C: Well, I don’t know. I mean I have very little social contact, I told you that.

$\mathrm{T}$ : So what if you were to imagine?

C: The same-I mean it doesn’t...

Here we see the client and therapist struggling to establish a working alliance, the client has difficulty getting into the task. He reminds his therapist that he has very little social contact, implying that she seems to have forgotten and perhaps is not listening to him. However, his therapist persists, and gently tries to show him how to work in an emotionally focused therapy; and the client seems to respond.

T: What do they say?

C: That I wasted my life, I wasted my potential...

T: "You wasted your potential." 
Contrasting Two Clients in Emotion-Focused Therapy for Depression 1:

The Case of "Tom," "Trapped in the Tunnel"

J.C. Watson, R. Goldman, \& L. Greenberg

Pragmatic Case Studies in Psychotherapy, http://pcsp.libraries.rutgers.edu

Volume 7, Module 2, Article 3, pp. 268-304, 06-05-11 [copyright by authors]

C: I had great expectations once you know?

T: So what? We expected a lot from you?

C: Yeah.

T: So we expected a lot from you?

C: Yeah that's right.

T: What have you done with it?

C: That's right and "What have you done with it?"

T: "What have you done with it?" What else?

C: I'm not sure—do you want something different rephrasing because you know?

T: I think there is more that you're saying that can actually help us understand what happens maybe, that you're not aware of?

Here the therapist asks for more as the criticisms do not fully match the intensity of the client's despair - she is working to evoke a strong enough sense of how bad it feels to evoke an alternative response that will effectively stand up to the critic.

C: Hmm, hmm.

T: There is something else that happens that you say to yourself? It's part of what keeps you down is this sense that you haven't achieved. Do you know what you should have achieved by now?

C: Pardon?

T: Tell him what you should have achieved by now?

C: I could have had a career.

T: You could have had a career?

C: I could have had a relationship.

T: A relationship?

C: Yeah.

$\mathrm{T}$ : Like you should be married by now?

C: Yeah-that's okay.

T: Okay married, what else?

C: Well, _(Inaudible).

T: So you don't have a career and you don't even have a relationship?

C: Hmm, hmm, that's right. (The therapist indicates to the client that he should change chairs)

T: How do you feel when that side says, "You don’t have a career?"

C: Bad, terrible, but I don't...

$\mathrm{T}$ : Stay with the terrible? 
Contrasting Two Clients in Emotion-Focused Therapy for Depression 1:

The Case of "Tom," "Trapped in the Tunnel"

J.C. Watson, R. Goldman, \& L. Greenberg

Pragmatic Case Studies in Psychotherapy, http://pcsp.libraries.rutgers.edu

Volume 7, Module 2, Article 3, pp. 268-304, 06-05-11 [copyright by authors]

C: Yeah, okay.

T: What's the bad feeling?

C: What is it?

T: Give me a sense...

C: I have a knot in my stomach.

T: You have a knot in your stomach-let's focus on that?

C: Okay.

T: Can you tell me about that-put some words to it, does it make you feel anxious when you sense that?

C: Yeah.

T: So its anxiety that makes you feel bad...?

C: I don't know.

$\mathrm{T}$ : What is the knot, the tightness in the stomach?

C: Well, I think it's that I recognize that it's true. I mean somewhat, I believe that- that's the problem.

T: Stay with the knot, what is the knot about—what does it do to you? (The therapist speaks softly, trying to gently coax the client to express the impact of the criticisims.)

C: I don't know.

T: This knot is it an anxious feeling...?

C: Anxious.

T: Does it feel anxious over here?

C: Yeah.

T: So this side makes you anxious when it says to you, "You failed, you're washed up, you don’t have a relationship, and you don't have a career?” Come back over here? (Client switching chairs).

C: (Client laughs).

T: Make him anxious now?

C: Do the same thing?

T: I am not sure but I want you to heighten that anxiety?

C: (Sighs)...

T: So... if you try to...so that we can get a sense of the process. Is this the process you do to make yourself anxious?

C: Yeah.

T: What else do you say to make yourself feel anxious?

C: I don't think there is anything new. I mean, you know, I'm useless, I'm washed up; I have no future that's pretty good... 
The Case of "Tom," "Trapped in the Tunnel"

J.C. Watson, R. Goldman, \& L. Greenberg

Pragmatic Case Studies in Psychotherapy, http://pcsp.libraries.rutgers.edu

Volume 7, Module 2, Article 3, pp. 268-304, 06-05-11 [copyright by authors]

T: “You don’t have a future, you are all washed up, there’s no future for you?”

C: Yeah.

T: What, you're finished?

C: Well, I don't know what finish means.

T: Well, what does no future mean?

C: Well it means-yeah, I don't know what I'm going to do?

T: So this side that was feeling more hopeless, but you see come here on this side (Client switching chairs). When that side says you're washed up and there is no future, you begin to feel hopeless right?

C: Right.

T: That's the feeling that comes up in the anxiety. It's like...

C: Yeah because I can't contest it.

T: So this side begins to feel hopeless-this side begins to feel despairing?

C: Hmm, hmm. That's right.

T: Okay, so that's the cycle?

C: Yeah that's right.

The therapist and client have been able to identify the cycle of self-criticism and despair that occurs within the client. However, the client is unable to be compassionate towards himself and request the critic to stop the negative self-evaluations. He has difficulty even acknowledging the impact of the anxiety and despair as he feels his assessment is accurate and objective. The therapist and client are still working towards agreement on the tasks and goals of therapy. It is important to remember that given the client's history, it is highly likely that he does not know how to set limits with others and reach out for support. These are behaviors he would need to learn in therapy as he comes to know and trust his feelings and recognize the needs implicit in his feelings.

To resolve two-chair work successfully, clients need to have a repertoire of complementary behaviors and a level of emotional processing skill that allows them to be aware of and label their feelings, to express them to another, and to know and communicate the needs that flow from those feelings. Clients who are neglected often have great difficulty being aware of their feelings and engaging in a dialogue that requires the expression of their feelings and the receipt of complementary behaviors. Tom needs to first develop a coherent narrative of the events in his life so that he can develop a framework to understand the source of his pain. Second, through an empathic relationship with his therapist he needs to form more positive introjects that would allow him to be more accepting, self-nurturing, and protective of himself. The development of positive introjects would also be an antidote to the neglect of himself and his needs and goals that have plagued his life thus far leaving him feeling washed up.

In the following excerpt we see his therapist trying to coax him into acknowledging the impact of his anxiety and self-criticism. But the client resists, saying that he does not need to 
The Case of "Tom," "Trapped in the Tunnel"

J.C. Watson, R. Goldman, \& L. Greenberg

Pragmatic Case Studies in Psychotherapy, http://pcsp.libraries.rutgers.edu

Volume 7, Module 2, Article 3, pp. 268-304, 06-05-11 [copyright by authors]

function as he has restricted his life so much that he can run on automatic pilot. The therapist's goal is to try to prod the client into caring for himself but it is too soon for Tom and only serves to reveal how stuck he is right now.

T: Tell this side about the despair, tell this side about how bad it feels inside?

C: It feels terrible-it's awful

T: Hmm, hmm. What does it feel like inside, when you say, “I’m washed up and I haven’t any future," what happens inside—-how do you manage?

C: It's like a big knot.

T: It's like a big knot, tell me what that feels like inside? (The therapist is gently coaxing the client to share his feelings)

C: Like a big knot in my stomach?

T: "So when you say that, it makes me anxious?” (Here the therapist is modeling a response.)

C: Yeah.

T: "You make me tight inside."

C: Hmm, hmm.

T: What happens when you feel tight inside?

C: What do you mean what happens_-it feels tight inside?

T: Can you function when you feel tight inside-does it paralyze you?

C: Well...

T: When I get anxious, I sometimes get paralyzed. What happens for you? (Here again the therapist is trying to model and provide a framework for the client to understand and articulate his experience.)

C: Well luckily, I don't have to function because I have managed, you know what I mean, my life has sort of been reduced to a pretty basic state - so I barely have to function, I don't have to think to tell the truth. I go through life on remote control mostly.

T: Hmm, hmm.

C: So I think that's how I function.

T: So it doesn't matter if you get anxious, is that what you are telling me? (Here the therapist deliberately tries to get the client to acknowledge that his anxiety does matter.)

C: Well...

T: You don't mind when you get a knot in your stomach, you don't mind if you do because it doesn't matter anyway?

C: That's not necessarily true.

T: You don't need to be happy or relaxed or kind of get your life back?

C: I don’t need to, maybe I don't know. (The client shrugs and looks upset) 
The Case of "Tom," "Trapped in the Tunnel"

J.C. Watson, R. Goldman, \& L. Greenberg

Pragmatic Case Studies in Psychotherapy, http://pcsp.libraries.rutgers.edu

Volume 7, Module 2, Article 3, pp. 268-304, 06-05-11 [copyright by authors]

T: You are looking upset. Are you feeling irritated with me?

C: Sorry-nno—absolutely not.

T: So tell this side about the knot?

C: Yeah. That it's because I agree, I think, and that I can't...But you know, I'm fairly good at intellectual debate if it's...If you know what I mean?

T: Hmm, hmm.

C: If it's a topic like I can talk about it...

$\mathrm{T}$ : But in here it is not so important what your mind thinks. I want to hear about how you feel...(The therapist speaks gently, trying to coach the client.)

C: Well that's what I mean, but I have no, it's like, it's no contest.

T: So do you like feeling anxious, do you like having a knot in your stomach?

C: I don't think so.

Here the client half-heartedly agrees that the anxiety is problematic; however, he does not feel able to counteract it. He says he is good at intellectual tasks but has difficulty describing and expressing his feelings. From this excerpt from the third session it is apparent that there are a number of factors that might make it difficult for the client to improve in the remaining thirteen weeks, including his deep sense of shame and his skepticism that the process can help him. He feels crippled by his feelings of despair and has given up all hope of being able to salvage his life. The client is scared of confronting the pain associated with the emotional neglect he experienced as a child. This neglect has continued into his adult years with the absence of close companionship and friendships. The client needs to grieve his losses and acquire a sense of what he needs to access in the future to make his life more rewarding and fulfilling. To do this he needs time to feel safe and strong enough to explore his feelings with his therapist. His therapist shifts gear and focuses on mirroring his experience of how terrible it feels without trying to differentiate it further. Currently he is reluctant to become aware of and explore his feelings as he finds it extremely stressful. He would rather not engage and stir things up. In order to facilitate agreement on the tasks and goals, the therapist focuses on his reluctance to deal with his pain before trying to work with the client on his sense of despair. The client describes his reluctance in this way.

C: For me it has been years of neglect. I feel I have to go through something to feel better. Therapy feels too hard.

T: It is like an overgrown garden and breaking the ground is hard.

C: Yeah it is a lot of work. It may just be easier to let it go.

T: So you don't see a future and are you asking what's the point?

C: Yeah, I need a blood transfusion

T: You really need something to revitalize you.

\section{Sessions 4-7: Continuing Difficulties Being in Therapy}

For the next four sessions Tom continued to struggle with his difficulties at being in 
therapy. Tom acknowledged that he felt he needed to test his therapist even though he felt that she was doing a good job. He noted that he did not dread therapy; however, he was still scared the therapist would pin him down and he would have to feel all the emotion. He felt that his emotions were too deep and that he had come this far in his life without attending to them. He expressed a fear of being sucked into a black hole.

\section{$\underline{\text { Session } 5}$}

In session 5 the therapist observed how Tom disqualified his experience and invalidated himself. The client was able to acknowledge that he invalidated himself and that a part of him did want to be in therapy. He observed that he was afraid of intimacy and that he made things go wrong in relationships because he acted distant and obsessed about his invention. His therapist suggested they do some two-chair work to try to resolve his ambivalence at being in therapy. The client was reluctant because he feared that if people really saw him they would not like him at all. It became clear that his most recurring emotion was embarrassment and shame.

\section{$\underline{\text { Session } 6}$}

By session 6 the client noted that he was feeling worse. He had started to think about what was happening in therapy, whereas before he had been able to shut out his pain. Now he had begun to feel insecure and overwhelmed by the realization that he feels hopeless about the future. His therapist suggested they do a two-chair exercise to see if they could mute the selfcriticism. This time the client was able to see how despairing the criticisms made him feel, like he was in a "black hole," and to tell the critic to stop punishing him. The critic agreed and asked the experiencing side to remind him not to be critical. This was a major step for the client as he began to enact more compassionate and self-protective behaviors.

\section{$\underline{\text { Session } 7}$}

At the seventh session the client reported that he did not feel well and expressed regret at the loss of a romantic relationship a number of years previously. He described how he had met his girlfriend through friends and how wonderful it had been at the beginning. However, after a brief affair the relationship ended, as Tom found the closeness and intimacy too painful. His girlfriend, impatient with his fear of connection, broke off the relationship. While exploring his feelings for his girlfriend, Tom became very scornful of himself and his behavior. The therapist suggested that they engage in a two-chair exercise to work with Tom's harsh, scornful critic.

C: Yeah it is sad. It is pathetic really.

T: Ahh! It is sad and it's pathetic?

C: Yeah. Look at this guy. He had the opportunity of a lifetime handed on a platter...I mean, you know...handed to him, right? He didn't have to find this woman, his friends found her (Pauses) and everything was just going along great and then...

Here the client is judging himself by external standards (LCPP, Level 3). He is drawing on a restricted range of information and not elaborating his inner worldview. However, he is 
The Case of "Tom," "Trapped in the Tunnel"

J.C. Watson, R. Goldman, \& L. Greenberg

Pragmatic Case Studies in Psychotherapy, http://pcsp.libraries.rutgers.edu

Volume 7, Module 2, Article 3, pp. 268-304, 06-05-11 [copyright by authors]

trusting and relying on his therapist more (SASB, Surface 2, Cluster 4) and disclosing his criticisms (SASB, Surface 2, Level 1); yet he castigates himself (SASB Surface 3, Cluster 6, and SASB, Surface 3, Cluster 7). His therapist tries to gently make him aware of how destructive and cruel he is being (SASB Surface 1, Cluster 4) towards himself. She tries to get the client to voice the harsh punitive things that he says to himself in order to develop an alternative more compassionate and self-protective response.

T: This is...this is...this is how you dump on yourself, is it? Okay so what else... what do you say, "You screwed up"?

C: Yeah.

T: Big time! "You're a loser".

C: Yeah that's right.

T: Say it.

C: "You are a loser".

T: Hmm. "I can't even keep a woman”?

C: Hmm Hmm.

T: “You can’t keep a woman”.

C: One that falls in love with you...... mean you know...?

T: So "here you are set up and you screw it up"?

C: That's right.

T: "How much more of a loser can you be"?

C: That's right. I can't imagine!

T: What else, how else do you dump...I mean do you see that you are continually dumping on him. Dump on him some more...

C: Aah..."You're hopeless.”

T: "You are hopeless..."

C: So what is the...you know?

T: What is this? (The therapist is inquiring about the client's hand gesture). You are kind of quite scornful of... and also dismissing of...you're quite despairing... when you throw up your hands in despair with him as if you are giving up on him with this scorn and kind of "ahh! You're not even worth...bothering with any more."

C: Yes that's right.

T: So do this then. Be scornful and kind of dismissive- - do it.

C: (Laughs) see now...

T: You are laughing at yourself.

C: Yeah. Now I am self-conscious.

T: But you are being scornful of him. (The therapist says this in a protective voice). 
The Case of "Tom," "Trapped in the Tunnel"

J.C. Watson, R. Goldman, \& L. Greenberg

Pragmatic Case Studies in Psychotherapy, http://pcsp.libraries.rutgers.edu

Volume 7, Module 2, Article 3, pp. 268-304, 06-05-11 [copyright by authors]

C: Uhm... you're hopeless. You are... (Pauses) pathetic.

T: You're pathetic.

C: Yeah.

T: Very pathetic. (The therapist indicates to the client to switch chairs).

C: (Laughs)

T: How do you feel when you hear that?

C: Terrible.

T: So this side is saying, "You're pathetic!" "You're just a total screw up.”

C: Bad.

T: Now stay with the feelings. Tell me about the awfulness...?

C: Well it is awful but I...I believe it, you know?

T: Stay with the feelings.

C: I can't dispute it.

T: I'm not asking you to dispute it. This is not something that you dispute rationally. So try to stay with how awful it feels.

Here the client thinks the therapist wants him to dispute his feelings; however, she urges him to stay with them in order to try to activate the implicit need and alternative action tendency in the emotion evoked by the harsh criticisms. This time the client is able to follow the therapist's lead. He stays with his feelings and expresses them to the "critic".

C: Yeah it feels awful, it feels terrible.

T: Tell him about how awful it feels...crushing or...?

C: Yeah it is paralyzing.

$\mathrm{T}$ : It is paralyzing and just totally immobilizes you, it freezes you.

C: Hmm Hmm.

T: Hmm Hmm. So "I can't move and you've got me locked in a corner"? What is happening inside? Your eyes look really tortured...

C: I am.

$\mathrm{T}$ : Is that how you're feeling?

C: Yes.

T: Tell him about the torture?

C: I am feeling very tortured.

T: What do you need?

C: (Sighs) I don't know.

T: “Stop it, back off”? 
The Case of "Tom," "Trapped in the Tunnel"

J.C. Watson, R. Goldman, \& L. Greenberg

Pragmatic Case Studies in Psychotherapy, http://pcsp.libraries.rutgers.edu

Volume 7, Module 2, Article 3, pp. 268-304, 06-05-11 [copyright by authors]

C: Yeah.

T: Say it.

C: Stop doing that.

T: And "back off."

C: And back off.

T: "This is hurting me."

C: This hurts me.

T: Say it again.

C: This hurts me a lot.

T: Can you say, "Stop it” again?

C: Stop it.

This is an important shift as the client has become aware of, labeled, and expressed his feelings. He has also set limits with the critic and told his critic to stop being so critical. However, the critic is reluctant to change. And in response, the client quickly moves out of the task to become analytical and self-evaluative.

\section{Sessions 8-12: Evoking and Exploring}

Sessions 9 and 10

After the seventh session the client seemed more engaged in therapy. He seemed to forge an alliance with his therapist and began to work to try to resolve some of his issues. At the next session the client reported that while last week had been difficult, he felt that he had crossed a threshold and felt more open. Over the next few sessions the client reported that his depression had begun to fluctuate and that he was not always as depressed; however, it was difficult for him to get motivated. He noted that he was trying to be less critical but he lacked direction and did not have a vision. The client admitted that he was still wavering in his commitment to therapy. He suggested that this was his core problem in many aspects of his life. He recalled that he first became depressed after dropping out of his engineering program. He had returned home for a year but his parents were unable to help him, which he saw as part of the problem. His therapist was very aware that a major problem for Tom was his inability to find a satisfying career that provided him with respect and self-gratification. She tried to explore some career options with him, but he refocused her saying that the root of his problem was that he could not commit and form attachments.

\section{$\underline{\text { Session } 10}$}

During the tenth session Tom admitted that he was scared to change as he engaged in a two-chair exercise to work with his feelings of despair and helplessness. During this task the client was able to set limits with the critic and to ask for support and encouragement. This time the critic agreed to be more reassuring and supportive and less critical. It became obvious during this exercise that the client had difficulty owning his strengths. He refused to acknowledge his 
good points. However, he did admit how important his project was to him. He tried to urge himself to become involved with it once more, but the experiencing side replied that he was too tired and drained and that perhaps he would take it up in another life. On the other hand, it became clear to Tom's therapist that the client was very attached to his project and that he became more alive when talking about it. The client acknowledged that when he moved he would have to change. At the end of the session he still felt anxious but recognized that he felt a little lighter.

\section{$\underline{\text { Session } 11}$}

At session eleven the client said he felt a little better as he had periods when he was not so depressed. The weather had become warmer, which made it easier for him to walk. He realized that he was exhausted from working shifts, which he had been doing for ten years. He wanted a change. He observed that he had started reading again. As he spoke about this activity his face lit up and he became more alive and energetic in the session. His therapist decided to focus on his passion and strength to try to shift his depression more. She was a little concerned about doing this as the client found himself in such a dead end; and yet she thought that it was important to access his positive feelings to help energize him and create possibilities. She suggested they do a two-chair exercise with the part that wanted to pursue the project and the part that had given up. The client agreed and was able to recognize how trapped he felt and how much he needed to escape. During this task the therapist tried a number of different metaphors to try to help the client symbolize his experience and become aware of his feelings.

$\mathrm{T}$ : So what does the side that is tired say?

C: I am too old. We are not getting anywhere and my back is sore.

T: How do you feel when he says I am too tired?

C: I feel overwhelmed, stuck.

T: So it feels like a ball and chain,..like a straight jacket? Is that how bad it is?

C: Yeah, it feels futile.

$\mathrm{T}$ : $\quad$ So it is as if the light goes out.

C: Yeah there is nothing to look forward to. I feel trapped in a tunnel.

T: What do you need? Do you need to get out of the tunnel?

C: Yes, I need out.

T: What is happening inside? Your voice sounds very quiet. Are you feeling vulnerable?

C: I feel useless, trapped.

T: It sounds as if you are almost dying in there. Do you need direction?

C: Almost, this feels like an albatross. I do need direction.

$\mathrm{T}$ : What else do you need from this side?

C: I need energy. 
T: O.K. Come over here to this side. (The therapist indicates the other chair). He is saying he is dying

C: Who is dying?

Here the client expresses some confusion during the task as the therapist's metaphor does not resonate with him.

T: I think it is the side that would like to get involved in the project again. So how does the tired side respond?

C: Sorry I don't want you to suffocate but I am so tired too.

T: What does the tired side need?

C: I need sleep and inspiration.

T: So you need a sense of direction?

C: Yeah a vision. I guess I could work on the second part of my invention. But I am putting it off till I go away.

During this task the client was not able to integrate the two sides, but he did acknowledge both his exhaustion as well as his need to feel alive and engaged in his project. Over the next few sessions he begins to think more about what he wants to do and to develop a sense of direction.

\section{Sessions 13-16: Transformation: Developing New Meaning and Alternative Responses}

\section{$\underline{\text { Session } 13}$}

During session 13 the client recognizes that the most difficult thing for him was his solitariness. However, he is not sure that he wants to be different. He feels that his reason for being is connected to his engineering project and that it is not his destiny to have an intimate relationship. He acknowledged that he does not want to be bothered by people. Reflecting on his impending move he realized he feels content at the thought of being closer to his brother and nephews and working on his project. He feels happy with the notion of a surrogate family, as he is terrified of intimacy. He feels that no one could love him and that they would reject him if they really knew what he was like. He does not feel able to provide support for a partner nor does he feel capable of maintaining a long-term relationship. He acknowledges his deep feelings of shame and that part of him that feels crippled. His therapist observes how he denigrates and shames himself and suggests that he might want to try a two-chair exercise to see if he could be more supportive and accepting. The client agrees.

$\mathrm{T}$ : So how do you feel over here?

C: I just want to disappear.

T: What do you need?

C: It just feels futile.

T: You look crushed and defeated. 
C: Yes, thinking about relationships is worse than the work issue.

T: Come over here. Can you crush him. I would like you to enact it—push him down.

C: (Punches palm).

T: How do you feel when he punches you?

C: Terrible.

T: Suffocated?

C: Like there is no hope.

T: What do you need?

C: I don't know.

T: Do you need him to stop? (Client nods) Can you say this?

C: Please stop, it's killing me. Stop it!

T: What is happening inside? There is no force in your voice you seem exhausted. Do you want him to leave you alone? (Client nods) Can you say this?

C: Leave me alone.

$\mathrm{T}$ : Come over here. (Therapist points to the other chair.)

C: How do I stop?

T: Well how do you respond over here?

C: I don't mean it.

The client is able to recognize the impact of his behavior and is able to set limits and ask the critical, shaming side to stop his behavior. Yet the critical side does not know how and neither side is able to come up with alternative solutions. In this last excerpt we see the client shift from being harsh and punitive with himself (SASB, Surface 3, Cluster 7) to being more protective and self-enhancing when he asks the critical side to stop (SASB, surface 3, Cluster 4). However, his neglectful side emerges once again when he says he does not know how to stop (SASB, Surface 3, Cluster 8). This exchange would be rated as Stage 5 on the Experiencing Scale as the client is actively exploring his shame and trying to come up with alternatives. Saying stop would be rated as Stage 6 on the Experiencing Scale as it indicates that the client is developing a new behavior, but he is unable to sustain the new behavior and reverts to criticizing himself once again (Experiencing Stage 2, and SASB Surface 3, Cluster 6).

\section{$\underline{\text { Session } 15}$}

At session 15 the client brought in a problematic reaction. He was more aware of how angry he was, especially in traffic, and riding the streetcar and questioning why he was reacting as he did. His therapist helped him explore his feeling using systematic, evocative unfolding. Together they searched for the trigger to the clients' anger. It emerged that the client was very angry and frustrated when he felt blocked. He realized that this was related in large part to how he felt about his project. As a result of his invention being rejected, he felt silenced and boxed in. As he explored his feelings of anger he recalled times when he was an adolescent and had felt 
The Case of "Tom," "Trapped in the Tunnel"

J.C. Watson, R. Goldman, \& L. Greenberg

Pragmatic Case Studies in Psychotherapy, http://pcsp.libraries.rutgers.edu

Volume 7, Module 2, Article 3, pp. 268-304, 06-05-11 [copyright by authors]

silenced at school by teachers who felt threatened by his intelligence. He agreed that he wanted to explore this further in the next session.

\section{Session 16}

In the 16th session the client reported that he was a lot less depressed. He was more energetic and thinking about his future. He still had difficulty concentrating and sleeping, and was not pursuing his interests with the intensity that he had prior to becoming depressed. However, he was making plans and felt sure that he would be back on track once he made his move. In this session he explored his anger with the political system and with old teachers. He realized that he was recalling memories of his school years that he had forgotten.

He agreed to do an empty chair exercise to try to work with his anger. He was able to tell his teachers that he felt their treatment of him had been unfair and undeserved. It was apparent that Tom felt let down not only by his parents but also by his teachers. He was unable to identify an adult who was supportive and able to guide him throughout his childhood and adolescence. Towards the end of the session he expressed his appreciation of the work he had done with his therapist and said he was looking forward to taking up his project again and beginning a new life in another city.

As we can see from the case study Tom engaged more fully in therapy during the last third of treatment. His therapist struggled to help him see how his self-neglect and criticisms contributed to his feelings of despair and shame. Yet, there was not enough time before his departure to process the full extent of his neglect and its impact on him or to develop a full repertoire of alternative behaviors and alternative introjects that would be more accepting and more nurturing and less judgmental of his behavior. In terms of the Experiencing Scale the client approached Stage 5 a few times, but did not sustain his exploration to reach Stage 6 consistently, which would have indicated that he had changed his behaviors and developed alternative ways of being in the world. From his SASB ratings we can see that he and his therapist were able to form a better alliance over time and were developing a common framework for his problems and ways of dealing with the issues that brought him to therapy. However, it was only at the penultimate and final session that the client recognized how unfairly he had been treated as a child and how disappointed he was with the adults in his world; and was able to access his anger. In terms of his treatment of self, he was learning to set limits with his critic and develop more nurturing and protective behaviors; but the balance between his negative and positive introjects was precarious and it was easy for him to slip back into being self-oppressive and rejecting of himself. The client needed to become more self-accepting and prizing of himself, however these behaviors can take time to build and are not always possible to attain in a short term treatment.

\section{THERAPY MONITORING AND USE OF FEEDBACK INFORMATION}

The therapy was monitored via the measures collected during and after each session, as described in the first section above, and via peer supervision of the therapist. 


\section{CONCLUDING EVALUATION}

\section{Outcome and Process Measures}

A review of the outcome measures that were collected at the beginning and end of therapy revealed that Tom's depression moderated over the course of the sixteen weeks. His score on the Beck Depression Inventory declined from 24, associated with severe depression, to 14, indicating that he was still mildly depressed at the end of therapy. He also reported changes in his interpersonal problems, as his total IIP score dropped from 1.77 to 1.36. His scores on the sub-scales of the IIP showed that he was less overly accommodating, self-sacrificing, and intrusive and needy. Overall the client reported that he was able to express his needs more easily, respect his limits more, and felt less needy in relation to others. He also reported that he coped differently with problems in so far as he suppressed his feelings less and was less reactive. Thus it seems the therapy had helped him become more aware of his feelings and that he was less inclined to use distraction to avoid his feelings.

In terms of the working alliance the client reported a good alliance on the Working Alliance Inventory (Horvath \& Greenberg, 1982). His scores ranged from 4.5-6.3 on a 7-point scale, with a mean of 5.33. He reported that he and his therapist had the same goals and a good understanding of his problems. This perspective may seem at odds with his therapist's view but much of what they were working on was to help the client overcome his fears of self-disclosure and of making his emotional experience explicit. It is likely that the client realized that he needed to explore his emotional experience but his own sense of shame as well as his own fear of the pain associated with his feelings made it difficult.

In terms of the Client Task Specific Change Measure-Revised (Watson, Greenberg, Rice \& Gordon, 1998; Watson, Shein, \& McMullen, 2009) described earlier, the client reported low to moderate amounts of in-session change. His scores ranged from 1.81 - 4.5 with a mean of 3.22 on a 7 point scale. As confirmed by his therapist and a review of the therapy transcripts, the client did report more changes from session 11 to 16. During this time the client reported that he was able to challenge his automatic thoughts and self-criticisms more, he felt better about himself, was more accepting and compassionate towards himself, and was more aware of how his thoughts, feelings, and behavior interacted. However, these changes were just beginning to emerge as therapy came to an end. It is likely that had the client been able to continue in therapy the changes he was making would have increased and become more entrenched.

\section{Factors Leading to Limited Success}

A number of factors can be identified that may have contributed to Tom's outcome at the end of treatment (Watson, Goldman, \& Greenbeerg, 2007). First, it is clear that the treatment was not long enough for him to deal successfully with the issues that brought him into therapy. A review of the sessions and the self-report data show that he was just beginning to participate more fully in treatment and beginning to record some changes as the 16 week treatment terminated and he left therapy to move to another city. He needed to learn to treat his experience 
differently and to build a more positive introject so that he could be more attentive to, accepting, and caring of his subjective experience (Watson, 2011).

Second, Tom was skeptical about therapy when he began tratment. In terms of the wellknown "Stages of Change" model (Prochaska, DiClemente, \& Norcross, 1992)—positing five sequential stages in a client's process of change from Pre-Contemplation, Contemplation, Preparation, Action, and Mainenance-Tom could be seen to be at the Contemplation stage when he entered therapy. It took him till session 11 to begin to engage in therapy more fully and enter the later stages.

Third, Tom's social support network was almost non-existent. He had few people he could rely on to support, nurture, and protect him from the difficulties he was facing or to help him overcome his deep sense of shame about his physical being.

Fourth, he entered therapy after a major life project had been criticized and dismissed. His social, personal, and work life was in ruins and he did not feel that he had the stamina and energy to rebuild, fearing that he was too old.

Fifth, the emotional neglect he had suffered as a child meant that he did not know how to process his feelings. In order to take care of himself and be more self-nurturing, self protective, and self-accepting, it would be important for him to become aware of and accept his feelings, to label them, and express them to others, and to know what he needed as a result of his feelings, and learn how to meet his needs in his environment. His difficulty processing his emotional experience had left him severely incapacitated in terms of establishing and maintaining interpersonal relationships and made it more difficult for him to deal with the very real difficulties he was experiencing in his work life.

Sixth, he had to recover from his deep sense of shame about his experience in order to engage in therapy more fully and to establish relationships with others outside of therapy. He had not learned how to nurture and care for himself adequately nor was he able to guide himself and to act in his own best interests. He needed to become less punitive and neglectful of himself so that he could be less ashamed and despairing.

During the course of the sixteen sessions, he and his therapist were working to develop his emotional processing skills and to develop more positive introjects so that he could be more responsive and caring of himself. Yet there was insufficient time to complete these tasks prior to the end of the sixteen-week treatment and Tom's departure to another city. Tom was just beginning to see light at the end of the tunnel when he left therapy, and he was cautiously optimistic about his future. Nevertheless, he had not been able to integrate fully new ways of being or seeing himself and the world to get through the tunnel into the sunlight. 
Contrasting Two Clients in Emotion-Focused Therapy for Depression 1:

The Case of "Tom," "Trapped in the Tunnel"

J.C. Watson, R. Goldman, \& L. Greenberg

Pragmatic Case Studies in Psychotherapy, http://pcsp.libraries.rutgers.edu

Volume 7, Module 2, Article 3, pp. 268-304, 06-05-11 [copyright by authors]

\section{REFERENCES}

Beck, A. T., Ward, C. H., Mendelson, M., Mock, J., \& Erbaugh, J. (1961). An inventory for measuring depression. Archives of General Psychiatry, 4, 561-571.

Benjamin, L.S. (1974). Structural Analysis of Social Behavior. Psychological Review, 81, 392425.

Benjamin, L.S. (1996). Interpersonal diagnosis and treatment of personality disorders (2nd ed.).New York: Guilford Press.

Derogatis, L. R. (1983). SCL-90: Administration, scoring and procedures manual for the revised version. Baltimore: Clinical Psychometric Research.

Elliott, R., Watson, J. C., Goldman, R., \& Greenberg, L. S. (2004). Learning emotion-focused therapy: The process-experiential approach to change. Washington, DC, US: American Psychological Association.

Goldman, R.N., Watson, J.S., \& Greenberg, L.S. (2011). Contrasting two clients in EmotionFocused Therapy for depression 2: The Case of "Eloise,” "It's Like Opening the Windows and Letting the Fresh Air Come In.” Pragmatic Case Studies in Psychotherapy, 7(2), Article 4, 305-338. Available: http://hdl.rutgers.edu/1782.1/pcsp_journal

Greenberg, L. S., Elliott, R. K., \& Foerster, F. S. (1990). Experiential processes in the psychotherapeutic treatment of depression. In C. D. McCann \& N. S. Endler (Eds.), Depression: New direction in theory, research and practice (pp. 157-185). Toronto, Ontario, Canada: Wall \& Emerson.

Greenberg, L. S. \& Pascual-Leone, J. (1995). A dialectical constructivist approach to experiential change. In R. A. Neimeyer \& M. J. Mahoney (Eds.), Constructivism in psychotherapy (pp. 169-191). Washington, DC: American Psychological Association.

Greenberg, L.S., \& Pascual-Leone, J. (2001). A dialectical constructivist view of the creation of personal meaning. Journal of Constructivist Psychology, 14, 165-186.

Greenberg, L.S., Rice, L.N. \& Elliott, R. (1993). Facilitating emotional change: The momentby-moment process. New York: Guilford Press.

Greenberg, L.S., \& Watson, J. (1998). Experiential therapy of depression: Differential effects of client-centerd relationship conditions and process experiential interventions. Psychotherapy Research, 8, 210-224.

Greenberg, L.S., \& Watson, J.C. (2005). Emotion-Focused Therapy for depression. Washington, D.C. American Psychological Association.

Horowitz, L. M., Rosenberg, S.E., Baer, B.A., Ureño, G., \& Villaseñor, V.S. (1988). Inventory of interpersonal problems: psychometric properties and clinical applications. Journal of Consulting and Clinical Psychology, 56, 885-892.

Horvath, A. O., \& Greenberg, L. S. (1989). Development and validation of the Working Alliance Inventory. Journal of Counseling Psychology, 36, 223-233.

Jacobson, N. S., \& Truax, P. (1991). Clinical significance: A statistical approach to defining meaningful change in psychotherapy research. Journal of Consulting and Clinical Psychology, 59, 12-19.

Klein, M.H., Mathieu-Coughlan, P. \& Kiesler, D.J. (1986). The experiencing scales. In L.S. Greenberg \& W.Pinsof (Eds.). The psychotherapeutic process: A research handbook (pp 21-71). New York: Guilford Press. 
Contrasting Two Clients in Emotion-Focused Therapy for Depression 1:

The Case of "Tom," "Trapped in the Tunnel"

J.C. Watson, R. Goldman, \& L. Greenberg

Pragmatic Case Studies in Psychotherapy, http://pcsp.libraries.rutgers.edu

Volume 7, Module 2, Article 3, pp. 268-304, 06-05-11 [copyright by authors]

Korman, L. M. (1998). Changes in clients' emotion episodes in therapy. (Doctoral dissertation, York University, 1998). Dissertation Abstracts International, 59, 2422 B.

Lorr, M., \& Strack, S. (1999). A study of Benjamin's eight-facet Structural Analysis of Social Behavior (SASB) model. Journal of Clinical Psychology, 55, 207-215. Available at: http://web.comhem.se/u68426711/14/Lorr99.pdf

Paivio, S. C. \& Greenberg, L. S. (1998). Experiential theory of emotion applied to anxiety and depression. In W. F. Flack, Jr. \& J. D. Laird (Eds.), Emotions in psychopathology: Theory and research. Series in affective science (pp. 229-242). London: Oxford University Press.

Pos, A. E., Greenberg, L. S., Goldman, R. N., \& Korman, L. M. (2003). Emotional processing during experiential treatment of depression. Journal of Consulting and Clinical Psychology, 71, 1007-1016.

Prochaska, J.O., DiClemente,, C.C., \& Norcross, J.C. (1992). In search of how people change: Application to addictive behaviors. American Psychologist, 47, 1102-1114.

Rice, L. N. \& Greenberg, L. S. (Eds.). (1984). Patterns of change. New York: Guilford.

Rice, L.N., Koke, C.J., Greenberg, L.S. \& Wagstaff, A.K. (1979). Manual for Client Vocal Quality (Vols I \& II). Toronto, Ontario, Canada: Counseling Development centre, York University.

Rice, L. N., \& Wagstaff, A. K. (1967). Client voice quality and expressive style as indexes of productive psychotherapy. Journal of Consulting Psychology, 31(6), 557-563.

Rosenberg, M. (1965). Society and the adolescent self-image. Princeton, New Jersey: Princeton University Press.

Spitzer, R., Williams, J., Gibbon, M., \& First, M. (1995). Structured Clinical Interview for DSM$I V$. New York, NY: American Psychiatric Press Inc.

Steckley, P. \& Watson, J.C. (June, 2005). An examination of the relationship between clients' attachment experiences, their internal working models of self and others, and therapists' empathy in the outcome of process-experiential and cognitive behavior therapies. Paper presented to the International Society for Psychotherapy Research’s Annual Conference in Montreal, Canada.

Toukmanian, S. G. (1986). A measure of client perceptual processing. In Leslie S. Greenberg and William M. Pinsof (Ed.), The psychotherapeutic process: A research handbook (pp. 107-130). New York, NY: Guilford Press.

Toukmanian, S. G. (1992). Studying the client's perceptual processes and their outcomes in psychotherapy. In S.G. Toukmanian and D.L. Rennie (Eds.), Psychotherapy process research: Paradigmatic and narrative approaches (pp. 77-107). Newbury Park, CA: Sage Publications.

Watson, J.C. (2011). The process of growth and transformation: Extending the process model. Person Centered and Experiential Psychotherapy, 10, 11-27.

Watson, J.C., \& Bedard, D. L. (2006). Clients' emotional processing in psychotherapy: A comparison between cognitive-behavioral and process-experiential therapies. Journal of Consulting and Clinical Psychology, 74, 152-159.

Watson, J.C., Goldman, R.N., \& Greenberg, L.S. (2007). Case studies in emotion-focused treatment of depression: A comparison of good and poor outcome. Washington, D.C.: American Psychological Association. 
Watson, J. C., Gordon, L. B., Stermac, L., Kalogerakos, F., \& Steckley, P. (2003). Comparing the effectiveness of process-experiential with cognitive-behavioral psychotherapy in the treatment of depression. Journal of Consulting and Clinical Psychology, 71, 773-781.

Watson, J. \& Greenberg, L. (1996). Emotion and cognition in experiential therapy: A dialecticalconstructivist position. In H. Rosen \& K Kuelwein (Eds.), Constructing realities: Meaning-making perspectives for psychotherapists. San Francisco: Jossey-Bass.

Watson, J. C., Greenberg, L. S., Rice. L.N. \& Gordon, L. (1998). Client Task Specific Change. Unpublished manual, Department of AECDCP, OISE/University of Toronto.

Watson, J.C., Shien, J. \& McMullen, E. (2009). An examination of clients' in-session Changes and their relationship to the working alliance and outcome. Psychotherapy Research, 4, 1-10.

Weissman, A. N., \& Beck, A. T. (1978). Development and validation of the Dysfunctional Attitude Scale. Paper presented at the 12th annual meeting of the Association for the Advancement of Behavior Therapy, Chicago, IL. 
The Case of "Tom," "Trapped in the Tunnel"

J.C. Watson, R. Goldman, \& L. Greenberg

Pragmatic Case Studies in Psychotherapy, http://pcsp.libraries.rutgers.edu

Volume 7, Module 2, Article 3, pp. 268-304, 06-05-11 [copyright by authors]

Figure 1. Benjamin's $(1974,1996)$ Eight-Facet, Structural Analysis of Social Behavior Model. From Lorr and Strack (1998, p. 209).

\section{Surface 1: Focus on the Other}

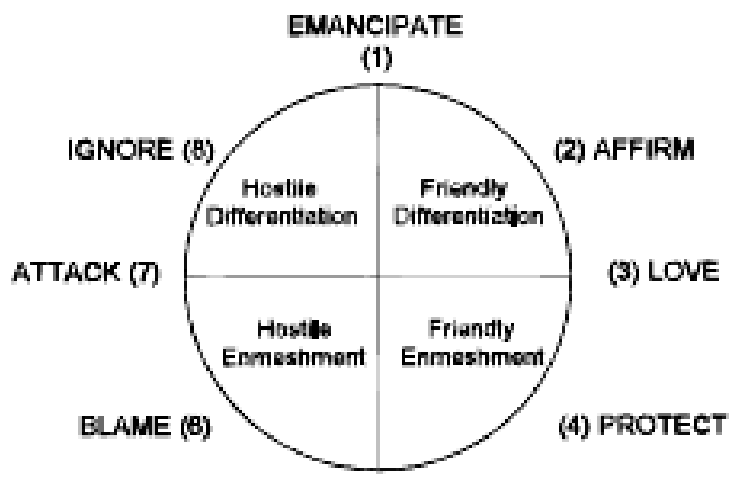

(5)

CONTROL

Surface 2: Focus on the Self

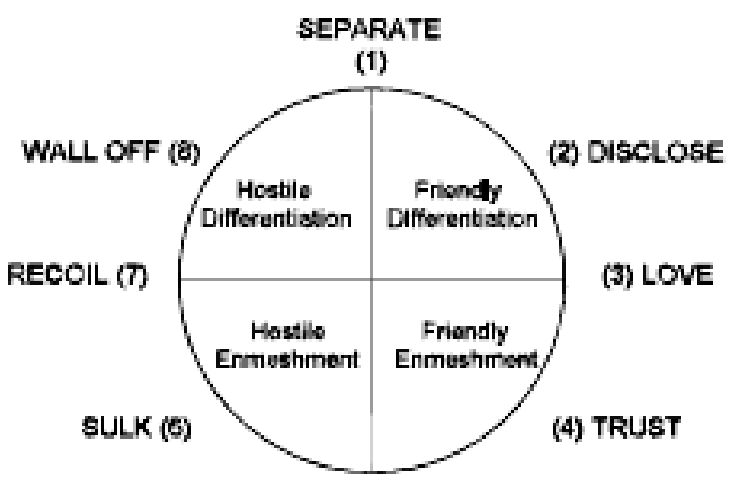

(5)

SUEMIT

Surface 3: Introject

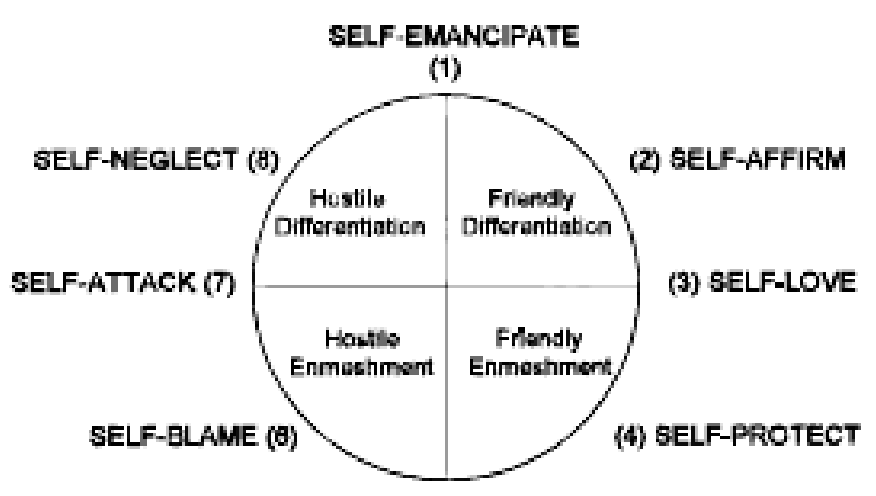

(5)

SELF-CONTROL 